\title{
Effects of maltodextrin concentration and inlet temperature on the physicochemical properties of spray-dried kuini powder
}

\author{
Yu Von Germaine Chng ${ }^{\mathrm{a}}$, Lee Sin Chang ${ }^{\mathrm{b}}$, Liew Phing Pui ${ }^{\mathrm{a}^{*}}$ \\ ${ }^{a}$ Department of Food Science with Nutrition, Faculty of Applied Sciences, UCSI University, No. 1, Jalan Menara Gading, UCSI Heights, \\ 56000 Cheras, Kuala Lumpur, Malaysia \\ ${ }^{b}$ Department of Food Sciences, Faculty of Science and Technology, Universiti Kebangsaan Malaysia, 43600 UKM Bangi, Selangor, Malaysia
}

Received 23rd October 2019 / Accepted 23rd November 2020

\begin{abstract}
Kuini (Mangifera odorata) is known for its intense flavour, attractive colour, rich fibre content and antioxidant properties. However, its short shelf life (bruise within a week) limits the availability of this fruit. Hence, spray drying was proposed to transform this fruit into powder to increase its application. The maltodextrin concentration of $5-20 \%(\mathrm{w} / \mathrm{w})$ and inlet temperatures of $140-180^{\circ} \mathrm{C}$ were applied to produce kuini powders. The effect of maltodextrin concentrations at constant inlet temperature $\left(160^{\circ} \mathrm{C}\right)$ showed that a higher amount of maltodextrin $(20 \% \mathrm{w} / \mathrm{w})$ produced powder with a low water activity $(0.16$ $\pm 0.01 \mathrm{Aw})$, moisture content $(2.16 \pm 0.60 \%)$ and hygroscopicity $(20.45 \pm 0.60 \mathrm{~g} / 100 \mathrm{~g})$ but the orange colour of the powder turned pale. The kuini powder was further spray dried at different inlet temperatures at constant optimal maltodextrin concentration $(20 \% \mathrm{w} / \mathrm{w})$. The kuini powder that was spray dried at $160^{\circ} \mathrm{C}$ had the optimal properties: low water activity $(0.17 \pm 0.01 \mathrm{Aw})$ and hygroscopicity $(22.12 \pm 0.09$ $\mathrm{g} / 100 \mathrm{~g})$ with high water solubility index, WSI $(79.90 \pm 1.85 \%)$ and wettability $(279 \pm 8 \mathrm{~s})$, indicating the powder can be applied as a food ingredient with high solubility. The optimal spray-drying condition for the production of kuini powder was $20 \%(\mathrm{w} / \mathrm{w})$ maltodextrin concentration at $160^{\circ} \mathrm{C}$ inlet temperature to have the highest yield of $43.08 \pm 2.77 \%$. Eventhough the reconstituted kuini powder had lower viscosity, colour and $\beta$-carotene content than kuini juice, this study showed the feasibility of production of kuini powder using spray drying operation which may broaden its application in the food industry.
\end{abstract}

Keywords: $\beta$-carotene, inlet temperature, kuini, maltodextrin, solubility, spray-drying

\section{INTRODUCTION}

Fruits, having a high content of moisture, are perishable and difficult to be sold as fresh produce, causing estimated post-harvest losses of over 20-30\% (Cano-Chauca et al., 2005). To prolong the shelf life of fruits, a few processing and preservation methods such as drying (Gallali et al., 2000), chemical treatment (Oms-Oliu et al., 2010) and packaging (Kader et al., 2009) can be applied. Dehydration by spray-drying is one of the common preservation methods used in the food industry (Chew et al., 2019) to produce the dried powder. Spray-drying involves the transformation of a liquid state feed into a dry particulate. The feed in the form of fluid is atomised and the liquid droplets are dried when in contact with hot air stream in the drying chamber (Angel et al., 2009). This results in products with a reduction of total volume and prolonged shelf life, reducing the space for transport and wastage of these fruits is also decreased (Singh et al., 2013).

*Author for correspondence: Liew Phing Pui, Department of Food Science with Nutrition, Faculy of Applied Sciences, UCSI University, No. 1, Jalan Menara Gading, UCSI Heights, 56000 Cheras, Kuala Lumpur, Malaysia. Email - puilp@ucsiuniversity.edu.my 
However, spray-drying of food that is rich in sugar, such as fruit juices, may result in unfavourable powder that is sticky, hygroscopic and hard to solubilise. This is due to the high content of low molecular weight sugars such as sucrose, fructose and glucose, and acids such as citric acid which have a low glass transition temperature (Jaya \& Das, 2004). This leads to reduced product yield and the caking of powders. Drying agent such as maltodextrin is often added into the spray-drying of fruit juices to facilitate the drying process (Adhikari et al., 2004). These drying agents work by increasing the glass transition temperature of the powder, reducing its stickiness (Chang et al., 2018a; Truong et al., 2005).

There have been many studies on the production of powder through spray-drying, such as watermelon (Quek et al., 2007), pineapple (Wong et al., 2015), eggplant (Chang et al., 2020a), cempedak (Pui et al., 2020a; Gopinathan et al., 2020) and papaya (Chang et al., 2020b). To the best of the authors knowledge, there are limited reports available on spray drying of kuini fruit. Kuini (Mangifera odorata) is a species of mango that is native to South East Asia, which is one of the underutilised Mangifera species discovered in Malaysia (Lasano et al., 2019). The fruit is orangeyellow in colour, fibrous, juicy, with a strong turpentine-like flavour and its flesh is sweeter than that of a common mango ( $\mathrm{Lim}, 2012)$. There are that studies reported the potent antioxidant activities (Loo \& Pui, 2020) and antibacterial activities (Adnan et al., 2018) of kuini fruit. In addition, the storage stability of kuini powder through packaging (Loo \& Pui, 2020) and incorporation of microencapsulated probiotics in kuini juice (Lai et al., 2020) have been reported recently. Even though kuini has been available locally, this precious fruit is still not known by many and is often underutilised (Kozai et al., 2005). The short shelf life (bruise within a week) of this fruit also brings about much wastage. Furthermore, the seasonal postharvest behaviour of kuini also reduces the availability of the fruit.

Hence, this research was conducted to produce kuini powder by spray-drying the kuini juice. The production of kuini powder would enhance the potential applications in various food industries i.e. as a functional ingredient in beverages, bakery, or healthy food products. The effects of different inlet temperatures and maltodextrin concentrations on the physicochemical properties of the spray-dried kuini powder were studied and the properties between fresh kuini fruit and optimised spraydried reconstituted kuini powder were compared. Inlet temperature and maltodextrin concentration were selected as the factors because these two parameters have been reported as important factors in the production of shelf-stable spraydried powder (Ferrari et al., 2012; Gallo et al., 2011; Shavakhi et al., 2012), besides feed flow rate.

\section{MATERIALS AND METHODS}

\section{Materials}

Fresh kuini fruits (Mangifera odorata) were collected and purchased from a local wholesale wet market in Selangor, Seri Kembangan, Selangor. The fruits at the commercial maturity stage $(0.6 \pm 0.1 \mathrm{~kg})$, uniform in size and green skin with no presence of external injury were selected. Maltodextrin (DE 10) used for spray drying was procured from Bronson and Jacobs Sdn. Bhd., Malaysia. All analytical grade chemicals used for analysis were purchased from Sigma-Aldrich (Dorset, United Kingdom) unless otherwise stated.

\section{Preparation of spray-drying feed}

The kuini pulps were homogenised separately using a blender (MX-SM1031, Panasonic, Malaysia) at high speed (12000 rpm) until it became smooth. The blended kuini pulps were diluted in distilled water to standardise the juice to a total soluble solid (TSS) content of $12^{\circ}$ Brix, measured using a digital refractometer MA $871(0$ $-85^{\circ}$ Brix) (Milwakee, Romania). The juices were then filtered using a filter cloth before spraydrying. A known amount of maltodextrin was added into $200 \mathrm{~g}$ of filtered juice and the mixture was filtered again in order to ensure smooth consistency (i.e., free from the solid matter) (Chang et al., 2018a).

The effects of inlet temperature and maltodextrin concentration on the spraydrying of kuini

The spray-drying experiments were carried out based on the One-Factor-At-A-Time (OFAT) approach with four different maltodextrin 
concentrations $(5-15 \% \mathrm{w} / \mathrm{w})$ and five different inlet temperatures $\left(140-180^{\circ} \mathrm{C}\right)$. The spray-drying of kuini powder was performed using a mini spray-dryer (Büchi Model B-290, Büchi Labortechnik AG, Switzerland). Prior to drying, the spray dryer was set at an aspirator rate of $100 \%$ and the inlet temperature of $160^{\circ} \mathrm{C}$, which is the middle parameter of the inlet temperature factor. The pump setting at $20 \%$ was activated once the desired inlet temperature was reached, nozzle speed was set at 5 and the compressed air flow rate was set at $40 \mathrm{~mm}(600 \mathrm{~L} / \mathrm{h})$ (Chang et al., 2020a). The spray-dryer was allowed to pump distilled water for the first 15 minutes in order to achieve internal equilibrium. After that, the spray drying feed with the addition of different maltodextrin concentrations (5, 10, 15 and 20\% $\mathrm{w} / \mathrm{w}$ ) and known TSS (measured before spray drying) was pumped into the spray dryer and the powder was collected from the cyclone. Physicochemical analyses of the powders produced with different maltodextrin concentrations were performed for the determination of the optimised maltodextrin concentration for the production of kuini fruit powder.
In the second part of the experiment, the spray-drying of kuini juice was repeated at 140 , 150, 160,170 and $180^{\circ} \mathrm{C}$. Selection of inlet temperature was based on observations made during preliminary work on spray-dried kuini powder, in which the powder that was spray-dried at a temperature below $140^{\circ} \mathrm{C}$ appeared sticky and wet while at a temperature above $180^{\circ} \mathrm{C}$ was yellowish due to burning. Meanwhile, the maltodextrin concentration was kept constant at $20 \%(\mathrm{w} / \mathrm{w})$ (the optimised concentration from the first part of the study). Physicochemical analyses were conducted to determine the optimised inlet temperature condition. The optimised powder obtained from the spray drying was reconstituted and its properties were compared with the fresh kuini juice.

\section{Characterisation of physicochemical properties of spray-dried kuini powder Process yield}

The process yield of the spray-dried kuini powder was calculated using the following formula (Pui et al., 2020b):

$$
\text { Process yield }(\%)=\frac{\text { Mass of spray-dried powder }(\mathrm{g})}{\text { Dry mass of kuini juice }(\mathrm{g})+\text { Mass of maltodextrin }(\mathrm{g})} \times 100 \%
$$

(Equation 1)

\section{Colour}

The HunterLab's ColorFlex Ez Colorimeter (Hunterlab, US), equipped with EasyMatch QVER software, was used to determine the colour of the samples. The colorimeter was standardised against a black tile followed by a white tile before analysis. Kuini juice or spray-dried kuini powder was placed in a sample cup and placed on a sample port before analysis. The data was expressed in terms of $\mathrm{L}^{*}, \mathrm{a}^{*}$ and $\mathrm{b}^{*}$ values, representing degree of lightness or darkness, degree of redness or greenness and degree of yellowness or blueness, respectively (Pui et al., 2018). The colour difference was calculated by the following equation (Chang et al., 2018b).

$$
\text { Difference in colour }=\sqrt{\left(\mathrm{L}_{0}^{*}-\mathrm{L}^{*}\right)^{2}+\left(\mathrm{a}_{0}^{*}-\mathrm{a}^{*}\right)^{2}+\left(\mathrm{b}_{0}^{*}-\mathrm{b}^{*}\right)^{2}}
$$

where $\mathrm{L}_{0}^{*}, \mathrm{a}_{0}^{*}$ and $\mathrm{b}_{0}^{*}$ are the lightness, redness and yellowness values of the fresh juice, and $\mathrm{L}^{*}, \mathrm{a}^{*}$ and $\mathrm{b}^{*}$ are the lightness, redness and yellowness values of the reconstituted powders.

\section{Water activity}

Water activity was measured using water activity meter (AquaLab Pre, METER Group, US) (Pui et al., 2020). The device was switched one hour before to warm up. Two grams of spray-dried kuini powder were weighed into a container and placed in the sample port of the water activity meter and read at room temperature.

\section{Moisture content}

The moisture content of the spray-dried kuini powder was determined in accordance with Quek 
et al. (2007) with some modification. Two grams of powder were weighed in an aluminium cup and dried in an oven at $105^{\circ} \mathrm{C}$ for 24 hours. The moisture content of the powders was calculated using the equation below.

$$
\text { Moisture content }(\%)=\left(\mathrm{M}_{\mathrm{i}}-\frac{\mathrm{M}_{0}}{\mathrm{M}_{\mathrm{i}}}\right) \times 100 \%
$$

where $\mathrm{M}_{0}$ is defined as the initial mass of the powder and $\mathrm{M}_{\mathrm{i}}$ is defined as the final mass of the powder.

Hygroscopicity. The hygroscopicity measurement was modified from Cai \& Corke (2000). Two grams of spray-dried kuini powder was placed in a pre-weighed $100 \mathrm{~mL}$ beaker. The powder was then placed into a glass desiccator maintained at a relative humidity of $81 \pm 2 \%$ by filling the bottom part of the desiccator with saturated ammonium sulphate solution. The powder was weighed after a week and the hygroscopicity was expressed as $g$ of moisture per $100 \mathrm{~g}$ of dry solids.

$$
\text { Hygroscopicity } \left.(\mathrm{g} / 100 \mathrm{~g})=\frac{\text { Final weight of sample }(\mathrm{g})-\text { Initial weight of sample }(\mathrm{g})}{\text { Initial weight of sample }(\mathrm{g})} \quad \text { (Equation } 4\right)
$$

\section{Bulk density}

The method described by Mishra et al. (2013) was used to measure the bulk density of the powder samples. Five grams of spray-dried kuini powder was added to a $10 \mathrm{~mL}$ graduated measuring cylinder. The measuring cylinder was tapped 3 times and the volume occupied by the powder was recorded. The bulk density was expressed as the ratio of the mass of powder to the volume occupied by the powder.

Phytoremediation is a commercially viable and promising technology that helps to accumulate heavy metals from contaminated land and water bodies. This solar-driven technique does not lead to the production of sludge; it doesn't lead to environmental disturbance and is cost-effective, making it an attractive technology to use. Although phytoremediation has lots of advantages and it helps to reduce soil pollution caused by metalloids. However, the in-situ effectiveness of phytoremediation is heavily dependent on several factors like (i) climate of the region (ii) soil type (iii) plant capability to utilise metals. Therefore field trials are required to improve the accuracy of predictive models. Naturally occurring plants have very limited maintenance requirements and a low-cost process. In conclusion, it needs to be stressed that non-edible plants should be used to avoid bioaccumulation and biomagnification. Phytomining process can be implemented for the recovery of the heavy metals by incinerating the metal accumulator crops. Large scale application of various phytoremediation techniques such as phytotransformation, phytoextraction, phytovolatilisation, and phytovolatilisation, etc. will be an excellent sustainable method for recycling and reusing of heavy metals to keep the environment safe, green, and resourceful for future generations.

$$
\text { Bulk density }(B D)=\frac{\text { Weight of powder }(\mathrm{g})}{\text { Volume of powder }(\mathrm{mL})}
$$

\section{Water solubility index (WSI)}

To determine the water solubility index (WSI) of the spray-dried kuini powder, $1 \mathrm{~g}$ of powder was added with $10 \mathrm{~mL}$ of water and mixed vigorously in a $50 \mathrm{~mL}$ Falcon tube. The mixture was then incubated in a water bath at $37 \pm 1{ }^{\circ} \mathrm{C}$ for 30 minutes to allow the powder to completely dissolve (Phoungchandang \& Sertwasana, 2010). The solution was centrifuged at $6454 \times g$ (Model 4200, Kubota, Tokyo, Japan) for 10 minutes. The supernatant was collected in a pre-weighed aluminium cup and immediately oven dried at 105 
$\pm 1^{\circ} \mathrm{C}$ for 5 hours. The weight of the remaining residue on the aluminium cup was recorded after drying. The solubility of the powder was calculated by the following equation:

$$
\text { Water solubility index }(\%)=\frac{\text { Weight of dried powder }(\mathrm{g})}{\text { Weight of original powder }(\mathrm{g})} \times 100 \%
$$

(Equation 6)

\section{Wettability}

The wettability of the spray-dried kuini powder was assessed according to the method reported by Marques et al. (2014). One gram of the powder was added to $100 \mathrm{~mL}$ of distilled water in a 250 $\mathrm{mL}$ beaker at $25 \pm 1^{\circ} \mathrm{C}$. The time required to completely dissolve the sample was recorded and indicated as wettability of the powder.

\section{Preparation of optimised reconstituted} powder The reconstitution of the optimised kuini powder was performed as suggested by Grabowski et al. (2008) with some modifications. The powder was reconstituted to the initial TSS contents of the spray-drying feed. Around $5.5 \mathrm{~g}$ of spray-dried kuini powders were added into $50 \mathrm{~mL}$ warm water. The mixture was stirred to solubilise the powder and the TSS content was examined using a digital refractometer (MA887, Milwaukee Instruments, Inc., North Carolina, USA) (0$85^{\circ}$ Brix). The powder was added continuously until the TSS achieved the initial TSS (before inserted into the spray drying system). Then, the viscosity, $\mathrm{pH}$, colour and $\beta$-Carotene content of the reconstituted powder were measured.

\section{Analysis of the reconstituted powder Viscosity}

A Brookfield viscometer (model DV-II+ Pro, Brookfield, US) equipped with Rheocalc software was used to measure the viscosity of the reconstituted powder. An LV-3 spindle was selected to measure the viscosities of the fresh kuini juice as well as the reconstituted powders (Chang et al., 2020).

\section{pH value}

The $\mathrm{pH}$ value of the samples was measured using a digital $\mathrm{pH}$ meter (Jenway, UK). The calibration of the $\mathrm{pH}$ meter was done using a $\mathrm{pH}$ buffer 7.0 followed by a $\mathrm{pH}$ buffer 4.0 . The probe of the $\mathrm{pH}$ meter was inserted into the sample and read at room temperature $\left(25 \pm 1^{\circ} \mathrm{C}\right.$ ) (Chang et al., 2020b).

\section{Colour}

The colour of fresh kuini juice and the reconstituted powder was analysed as described above.

\section{$\beta$-carotene content}

The $\beta$-carotene extraction of fresh kuini juice and reconstituted powder was performed as described by Carvalho et al. (2012) with some modifications. Three grams of sample were weighed and added with $10 \mathrm{~mL}$ of distilled water with continuous stirring using a spatula until fully dissolved. In the process of $\beta$-carotene extraction, successive addition of $20 \mathrm{~mL}$ acetone was made into the sample-water mixture. The solution was transferred into a funnel with a $250 \mathrm{~mL}$ Buchner flask, where the solution was filtered under a vacuum. This procedure was repeated thrice. One-third of the extract obtained was then transferred into a separatory funnel $(500 \mathrm{~mL})$ which contains petroleum ether $(20 \mathrm{~mL})$. Distilled water $(300 \mathrm{~mL})$ was added slowly into the solution and the aqueous phase was discarded. This procedure was repeated thrice with the addition of $200 \mathrm{~mL}$ water at the second and third extraction. After that, the extract was transferred through a funnel which contains anhydrous sodium sulphate $(15 \mathrm{~g})$ to a $50 \mathrm{~mL}$ round bottom flask. The petroleum ether was removed in a rotary evaporator at $35 \pm 1{ }^{\circ} \mathrm{C}$. Finally, the volume of the dried extract was made up to $1.5 \mathrm{~mL}$ using acetone and the samples were read at $450 \mathrm{~nm}$ using a UV-VIS spectrophotometer (Hach DR 6000 , Germany). A standard curve was generated using $\beta$-carotene solution $(5-25 \mu \mathrm{g} / \mathrm{g})$ for the determination of the $\beta$-carotene content.

\section{Statistical analysis}

The data collected was expressed in terms of mean \pm standard deviations. All the statistical analysis of the data collected from the experiment was analyzed using Minitab v.18 LLC (USA). One-way ANOVA was performed to determine the significant differences between the means of 
data collected $(\mathrm{p} \leq 0.05)$ using Tukey's Honest Significant Difference (HSD) test. A paired T-test was used to compare the mean of two independent samples.

\section{RESULTS AND DISCUSSION}

Table 1. Physicochemical properties of fresh kuini juice (spray drying feed) $(\mathrm{n}=3)$.

\begin{tabular}{lc}
\hline Physicochemical properties & Values \\
\hline $\mathrm{pH}$ & $4.52 \pm 0.06$ \\
Viscosity $(\mathrm{cP})$ & $3661.20 \pm 118.90$ \\
Colour measurement & \\
$\quad \mathrm{L}^{*}$ value & $54.94 \pm 0.87$ \\
$\mathrm{a}^{*}$ value & $15.43 \pm 1.51$ \\
$\mathrm{~b}^{*}$ value & $68.61 \pm 1.99$ \\
$\beta$-carotene content $(\mu \mathrm{g} / \mathrm{g})$ & $14.12 \pm 1.37$ \\
\hline
\end{tabular}

Notes: Data are presented as mean \pm standard deviation of triplicate determination. Abbreviations: $\mathrm{cP}=$ centipoise, $\mathrm{L}^{*}$ $=$ degree of lightness or darkness, $\mathrm{a}^{*}=$ degree of redness or greenness and $\mathrm{b}^{*}=$ degree of yellowness or blueness, $\mu \mathrm{g} / \mathrm{g}$ $=$ microgram per gram.

\section{Physicochemical properties of fresh kuini juice}

Table 1 shows the physicochemical properties of the fresh kuini juice used for the spray-drying process. The kuini juice used for spray drying was moderate acidic with high viscosity. To the best of the authors knowledge, there have been limited reports on the physical properties of kuini. Barbosa Gámez et al. (2017) reported that the titratable acidity of kuini fruit was $28.30 \pm 6.35$ $\mathrm{g} / \mathrm{kg}$ dry weight, which was lower than Mangifera indica (41.23 g/kg) but higher than Mangifera zeylanica $(21.93 \mathrm{~g} / \mathrm{kg})$, indicating kuini fruit has moderate acidity level. $M$. indica was reported to have lightness $\left(\mathrm{L}^{*}\right)$, redness $\left(\mathrm{a}^{*}\right)$, and yellowness $\left(b^{*}\right)$ values of 54.9-61.3, 11.5-14.4 and 39.6-48.3, respectively (Ribeiro et al., 2007). These values were closed to the colour of kuini, except the $\mathrm{b}^{*}$ value that was $68.61 \pm 1.99$, indicating kuini juice exhibited more yellowish and reddish as compared to mango. Overall, the kuini juice has a bright orange-yellowish colour. The $\beta$-carotene content of kuini juice was measured to be $14.12 \pm$ $1.37 \mu \mathrm{g} / \mathrm{g}$. Kuini peel was reported to contain $1.008 \pm 0.002 \mathrm{mg} / \mathrm{g}$ of $\beta$-carotene (Lasano et al., 2019). A lower value of $\beta$-carotene obtained in this study probably due to the addition of maltodextrin which diluted the $\beta$-carotene content in the juice. Meanwhile, Ndawula et al. (2004) reported that mango fruit had a $\beta$-carotene content of $59 \mu \mathrm{g} / \mathrm{g}$, which was higher than kuini in this study.

\section{Effects of maltodextrin concentration on process yield, outlet temperature, feed flow rate and powder condition}

Table 2 presents the process yield, outlet temperature, feed flow rate and powder conditions of the spray-dried kuini powders produced with maltodextrin concentrations of 5$20 \%(\mathrm{w} / \mathrm{w})$ under an inlet temperature of $160^{\circ} \mathrm{C}$. From Table 2, the outlet temperatures of the powders were $103-106^{\circ} \mathrm{C}$. All the outlet temperatures fall within the range of $90-110{ }^{\circ} \mathrm{C}$ as recommended by Caparino et al. (2012).

There were no significant differences $(\mathrm{p}>$ 0.05 ) in the process yield of the kuini powder, with the addition of different maltodextrin concentrations in the spray-dryer feed (Table 2). The process yield ranges from $24.61 \pm 0.65 \%$ to $29.27 \pm 3.64 \%$. According to Fang \& Bhandari (2012), the increase in maltodextrin concentration increases powder recovery. This is because maltodextrin increases the total solid content present in the feed. This in turn reduces its moisture content and further reduces the surface stickiness of low molecular weight sugars found abundantly in fruits. Hence, it increases the process yield as less powder would stick to the drying chamber (Quek et al., 2007). However, a contrast result was obtained in this study, probably due to the amount of maltodextrin used was lower than the study by Fang \& Bhandari (2012), which is $40 \%$.

Table 2 also shows that the feed flow rate of the spray drying process was not significantly affected ( $p>0.05$ ) with the addition of different maltodextrin concentrations. The feed flow rate ranged from $5.02 \pm 0.36 \mathrm{~g} / \mathrm{min}$ to $5.45 \pm 0.63$ $\mathrm{g} / \mathrm{min}$. This might be due to the spray drying feed has a similar smooth consistency and the feed flow rate did not significantly different. The kuini powder formed with the addition of $5 \%(\mathrm{w} / \mathrm{w})$ maltodextrin appeared sticky and coarse. However, when the maltodextrin concentration used was more than $10 \% \mathrm{w} / \mathrm{w}$, the powders formed were non-sticky and appeared fine and soft. Phisut (2012) reported that powders formed with a low concentration of drying agent turned 
out to be sticky. Meanwhile, powders formed at $5-10 \%(\mathrm{w} / \mathrm{w})$ maltodextrin had a brighter yellow colour. When maltodextrin concentration level was increased to $15 \%(\mathrm{w} / \mathrm{w})$ or more, the colour of the powders formed was pale yellow. Quek et al. (2007) also reported that when the addition of maltodextrin was more than $10 \%(\mathrm{w} / \mathrm{w})$, the watermelon powder produced would lose its attractive colour.

Table 2. The outlet temperature, process yield, feed flow rate, and powder conditions of kuini powder spray-dried with different concentrations of maltodextrin and constant inlet temperature $\left(160^{\circ} \mathrm{C}\right)(\mathrm{n}=3)$.

\begin{tabular}{ccccl}
\hline $\begin{array}{c}\text { Maltodextrin } \\
\begin{array}{c}\text { Concentration } \\
(\%)\end{array}\end{array}$ & $\begin{array}{c}\text { Outlet } \\
\text { Temperature } \\
(\mathbf{(} \mathbf{C})\end{array}$ & $\begin{array}{c}\text { Process Yield } \\
\mathbf{( \% )}\end{array}$ & $\begin{array}{c}\text { Feed Flow } \\
\text { Rate } \\
(\mathbf{g} / \mathbf{m i n})\end{array}$ & \multicolumn{1}{c}{ Powder Conditions } \\
\hline 5 & $103-105$ & $24.61 \pm 0.65$ & $5.02 \pm 0.36$ & $\begin{array}{l}\text { Sticky and coarse powder } \\
\text { with yellow colour }\end{array}$ \\
10 & $104-105$ & $26.90 \pm 2.29$ & $5.30 \pm 0.35$ & $\begin{array}{l}\text { Fine and soft powder with } \\
\text { yellow colour }\end{array}$ \\
15 & $104-106$ & $27.75 \pm 2.66$ & $5.29 \pm 0.41$ & $\begin{array}{l}\text { Fine and soft powder with } \\
\text { pale yellow colour } \\
\text { Fine and soft powder with } \\
\text { pale yellow colour }\end{array}$ \\
\hline
\end{tabular}

Data are presented as mean \pm standard deviation of triplicate determination.

Abbreviations: $\%=$ percent,${ }^{\circ} \mathrm{C}=$ degree Celsius, $\mathrm{g} / \mathrm{min}=$ grams per minute.

\section{Effects of maltodextrin concentration on colour of spray-dried kuini powder}

Table 3 shows the colour measurements of the spray-dried kuini powder produced with the addition of different maltodextrin concentrations $(5-20 \% \mathrm{w} / \mathrm{w})$. The powders had high lightness $\left(\mathrm{L}^{*}\right)$, low redness $\left(\mathrm{a}^{*}\right)$ and moderate yellowness $\left(b^{*}\right)$ value. The $L^{*}$ values of the powders were closer to 100 , which indicates that the powders formed were light in colour. The positive $\mathrm{a}^{*}$ value and $b^{*}$ value indicate that the powders produced were more reddish than greenness and more yellowish than blueness in colour, respectively.

The powder produced with the addition of $5 \%(\mathrm{w} / \mathrm{w})$ maltodextrin had the lowest $\mathrm{L}^{*}$ values. This was followed by powders produced with $10 \%(\mathrm{w} / \mathrm{w})$ maltodextrin concentration. Powders produced with maltodextrin concentration of more than $15 \%(\mathrm{w} / \mathrm{w})$ had lighter colours. This result was in accordance with the findings of Kha et al. (2010) and Mishra et al. (2013), where the lightness of the gac and amla powders were positively affected by the concentration of maltodextrin. Caparino et al. (2012) found that the lighter colour in spray-dried mango powder was due to the addition of white colour maltodextrin that contributed to the increase in lightness. The $a^{*}$ value of the powders decreased significantly by up to $58 \%$ from $4.63 \pm 0.35$ at $5 \%$ (w/w) maltodextrin to $1.95 \pm 0.22$ at $20 \%(\mathrm{w} / \mathrm{w})$ maltodextrin. On the other hand, the $b^{*}$ value of the powders decreased significantly by up to $23 \%$ from $38.32 \pm 2.06$ at $5 \%(\mathrm{w} / \mathrm{w})$ maltodextrin to $29.59 \pm 0.48$ at $20 \%(\mathrm{w} / \mathrm{w})$ maltodextrin. In the production of sweet potato and gac powders, there were also found that reduction of redness ( $a^{*}$ value) and yellowness (b* value) when the maltodextrin concentrations increased (Grabowski et al., 2006; Kha et al., 2010). Based on the colour profile, the powder produced with 5\% $(\mathrm{w} / \mathrm{w})$ maltodextrin was the most favourable because as it has the most resemblance to the colour of the fresh kuini juice. Up to date, there is a limited report on the production of spray-dried kuini powder.

\section{Effects of maltodextrin concentration on water activity and moisture content of spray- dried kuini powder}

Table 3 shows the water activity level of the powders produced with maltodextrin concentration of $5-20 \%(\mathrm{w} / \mathrm{w})$. From Table 3, it can be observed that the water activities of the powders were relatively low $(<0.24 \mathrm{Aw})$. At 15 $20 \%(\mathrm{w} / \mathrm{w})$ maltodextrin concentration, the water activity levels of the powders were the lowest. Meanwhile, the water activity levels of the powders were the highest at $5-10 \%$ (w/w) maltodextrin. This result was in agreement with the findings of Kha et al. (2010) and Quek et al. 
(2007), in which the water activities of the spraydried gac and watermelon powders decreased with the increased concentration of maltodextrins. As the water activity falls below 0.6 Aw, the growth of microorganisms is inhibited (Cauvain \& Young, 2008). Hence, the kuini powders produced with different maltodextrin concentrations were considered microbiologically stable as they all had a much lesser water activity level than 0.6 Aw. Powders with 15-20\% (w/w) maltodextrin were the most favourable in terms of water activity level. The water activity of kuini juice was $>0.90$, probably due to the presence of water that contributed to high water activity.

Table 3 shows the moisture content of kuini powders produced under different maltodextrin concentration $(5-20 \% \mathrm{w} / \mathrm{w})$. Powders with $5 \%$ $(\mathrm{w} / \mathrm{w})$ maltodextrin had the highest moisture content while powders with $20 \%$ (w/w) maltodextrin had the lowest moisture content. The moisture content of powders with 15-20\% $(\mathrm{w} / \mathrm{w})$ maltodextrin showed no significant difference $(p>0.05)$. The moisture content of the kuini powder decreased as maltodextrin concentration increased. Similar results were obtained in the studies of spray-dried pineapple powder by Abadio et al. (2004) and Jittanit et al. (2010) where the moisture content of the powders decreased with the increased maltodextrin concentrations by $15 \% \mathrm{w} / \mathrm{w}$ and $40 \% \mathrm{w} / \mathrm{w}$, respectively. Quek et al. (2007) also reported that the increase in maltodextrin concentration decreased the moisture content of watermelon powder. These studies suggested that adding more maltodextrin (up to $40 \% \mathrm{w} / \mathrm{w}$ ) increases the total solid content in the feed, which in turn reduces the amount of water for evaporation.

Powders with high moisture content tend to be stickier, lose their free-flowing capacity, and have low stability and bulk density (Hui et al., 2008). Hence, powder with low moisture content is essential for stability and storage (Phisut, 2012). Thus, kuini powders produced with $20 \%$ (w/w) addition of maltodextrin can be considered as the most favourable in terms of moisture content.

Table 3. Physicochemical analyses of spray-dried kuini powder under different maltodextrin concentrations and constant inlet temperature $\left(160^{\circ} \mathrm{C}\right)(\mathrm{n}=3)$.

Maltodextrin Concentration (\%)

Analyses

$10 \quad 15$

20

\begin{tabular}{|c|c|c|c|c|}
\hline Colour $\left(\mathrm{L}^{*}\right)$ & $85.87 \pm 0.41^{c}$ & $87.66 \pm 1.28^{b}$ & $89.40 \pm 0.10^{\mathrm{a}}$ & $90.16 \pm 0.19^{a}$ \\
\hline Colour $\left(a^{*}\right)$ & $4.63 \pm 0.35^{\mathrm{a}}$ & $3.43 \pm 0.70^{\mathrm{b}}$ & $2.20 \pm 0.21^{\mathrm{c}}$ & $1.95 \pm 0.22^{c}$ \\
\hline Colour (b*) & $38.32 \pm 2.06^{\mathrm{a}}$ & $34.83 \pm 2.28^{\mathrm{ab}}$ & $31.24 \pm 0.88^{\mathrm{b}}$ & $29.59 \pm 0.48^{\mathrm{b}}$ \\
\hline Water Activity $\left(\mathrm{A}_{\mathrm{w}}\right)$ & $0.23 \pm 0.03^{\mathrm{ab}}$ & $0.24 \pm 0.02^{\mathrm{a}}$ & $0.18 \pm 0.01^{\mathrm{c}}$ & $0.16 \pm 0.01^{\mathrm{c}}$ \\
\hline Moisture Content $(\%)$ & $5.11 \pm 0.58^{a}$ & $3.81 \pm 0.20^{\mathrm{b}}$ & $3.07 \pm 0.22^{\mathrm{bc}}$ & $2.16 \pm 0.60^{c}$ \\
\hline Bulk Density $(\mathrm{g} / \mathrm{mL})$ & $0.30 \pm 0.01^{\mathrm{a}}$ & $0.44 \pm 0.01^{\mathrm{a}}$ & $0.47 \pm 0.02^{\mathrm{a}}$ & $0.49 \pm 0.02^{\mathrm{a}}$ \\
\hline WSI $(\%)$ & $58.79 \pm 12.50^{\mathrm{a}}$ & $63.59 \pm 8.71^{\mathrm{a}}$ & $64.75 \pm 7.64^{\mathrm{a}}$ & $70.86 \pm 6.92^{\mathrm{a}}$ \\
\hline Wettability (s) & $220.33 \pm 30.83^{c}$ & $236.67 \pm 34.03^{b c}$ & $278.33 \pm 16.07^{\mathrm{bc}}$ & $299.33 \pm 11.59^{\mathrm{b}}$ \\
\hline Hygroscopicity (g/100g) & $24.90 \pm 0.61^{\mathrm{a}}$ & $23.08 \pm 0.99^{\mathrm{ab}}$ & $21.25 \pm 0.55^{\mathrm{bc}}$ & $20.45 \pm 0.60^{\mathrm{cd}}$ \\
\hline
\end{tabular}

Data are presented as mean \pm standard deviation of triplicate determination. Within the same row, different superscripts are significantly different at $\mathrm{p} \leq 0.05$, as measured by the Tukey's HSD Test. Abbreviations: $\%=$ percent, ${ }^{\circ} \mathrm{C}=$ degree Celsius, $\mathrm{L}^{*}=$ degree of lightness and darkness, $\mathrm{a}^{*}=$ degree of redness or greenness, $\mathrm{b}^{*}=$ degree of yellowness or blueness, $\mathrm{A}_{\mathrm{w}}=\mathrm{water}$ activity, $\mathrm{g} / \mathrm{mL}=$ gram per millilitre, WSI $=$ Water Solubility Index, $\mathrm{s}=$ second, $\mathrm{g} / 100 \mathrm{~g}=$ gram per 100 grams.

Effects of maltodextrin concentration on bulk density of spray-dried kuini powder

The bulk density of powder spray-dried with maltodextrin concentrations of $5-20 \%(\mathrm{w} / \mathrm{w})$ can be observed in Table 3. From the results obtained, maltodextrin concentration does not influence the bulk density. The bulk density of the powders ranged from $0.30 \pm 0.01$ to $0.49 \pm 0.02 \mathrm{~g} / \mathrm{mL}$. All 
the powders obtained in this study fall within the range reported by Hui et al. (2008), in which the bulk density of spray-dried powder varied from $0.3-0.7 \mathrm{~g} / \mathrm{mL}$. Spray-dried amla and gac powders also showed no significant difference in their bulk density when added with different concentrations of maltodextrins (Kha et al., 2010; Mishra et al., 2013). In contrast, Goula \& Adamopoulos (2010) found out that spray-dried orange powders of lower bulk density were produced at a higher concentration of maltodextrin. The effect was due to the properties of maltodextrin, which minimises thermoplastic particles from sticking.

\section{Effects of maltodextrin concentration on water solubility index and wettability of spray-dried kuini powder}

The WSI of kuini powder increased with an increased concentration of maltodextrin. The highest WSI was obtained when 20\% (w/w) maltodextrin was added to the feed before the spray drying process. A similar trend was observed by Vidović et al. (2014) where there was an increase of WSI when the maltodextrin concentration was increased during the spray drying of Satureja montana extract. According to El-Samahy et al. (2007), a higher WSI value showed a higher water dissolving ability of powder constituents. Hence, high values of WSI are favourable to give the powder a desired property. Meanwhile, the wettability of kuini powder was found to be increased when higher maltodextrin concentration (up to $20 \% \mathrm{w} / \mathrm{w}$ ) was used. A similar trend was observed by Chang et al. (2020a) in spray drying of "Terung Asam" powder. In addition, increased maltodextrin concentration resulted in a partial reduction in the powder wettability, although it increased powder moisture content. Furthermore, caking is more easily to occur in powders with higher moisture content, and this may contribute to their wetting ability because the liquid penetrates the pores more easily.

\section{Effects of maltodextrin concentration on hygroscopicity of spray-dried kuini powder}

Table 3 describes the hygroscopicity of powders produced using different maltodextrin concentrations $(5-20 \% \mathrm{w} / \mathrm{w})$. From Table 3, increasing the maltodextrin concentration from 5 to $20 \%(\mathrm{w} / \mathrm{w})$ reduced the hygroscopicity by up to $18 \%$, indicating the powder produced was less hygroscopic. This result is in agreement with Tonon et al. (2008) whereby at an inlet temperature of $160^{\circ} \mathrm{C}$, an increase in maltodextrin concentration from 10 to $30 \% \mathrm{w} / \mathrm{w}$ caused a reduction in hygroscopicity of acai powder. This is because maltodextrin is a material with low hygroscopicity. A similar pattern was also observed in the spray drying of cactus pear juice and betacyanin pigments by RodriguezHernandez et al. (2005) and Cai \& Corke (2000), respectively. High hygroscopic powders indicate that the powders have a higher tendency to absorb the moisture from the surrounding air. This leads to the powder becoming sticky and prone to caking. Thus, the storage stability of highly hygroscopic powders is relatively low (Sarabandi et al., 2014). Table 3 clearly shows that powders produced with maltodextrin concentration of $20 \% \quad(\mathrm{w} / \mathrm{w})$ had the significantly lowest hygroscopicity value which is more preferable.

\section{Optimum maltodextrin concentration}

Based on Table 3, the powder produced with the addition of $20 \% \quad(\mathrm{w} / \mathrm{w})$ maltodextrin concentration had the lowest moisture content $(2.16 \pm 0.60 \%)$ and water activity $(0.16 \pm 0.01$ $\mathrm{Aw})$. It was also one of the least hygroscopic powders with a hygroscopicity value of $20.45 \pm$ $0.60 \mathrm{~g} / 100 \mathrm{~g}$. The process yield of the powder was $29.27 \pm 3.64 \%$ with a feed flow rate of $5.32 \pm 0.70$ $\mathrm{g} / \mathrm{min}$ (Table 2). The powder formed was fine and soft, non-sticky and appeared to be pale yellow. Other than that, it had $L^{*}$ value of $90.16 \pm 0.19$, $a^{*}$ value of $1.95 \pm 0.22$ and $b^{*}$ value of $29.59 \pm$ 0.48 . Besides, the powder also had a bulk density of $0.49 \pm 0.02 \mathrm{~g} / \mathrm{mL}$, WSI of $70.86 \pm 6.92 \%$ and wettability value of $299.33 \pm 11.59 \mathrm{~s}$. The powder is considered to be of good wettability ( $\leq 300 \mathrm{~s}$ ). Therefore, the powder produced at $20 \%(\mathrm{w} / \mathrm{w})$ maltodextrin concentration was optimal.

Effects of inlet temperature on process yield, outlet temperature, feed flow rate, and powder condition

Table 4 shows the process yield, outlet temperature, feed flow rate and powder conditions formed under different inlet temperatures of $140-180^{\circ} \mathrm{C}$ at the constant maltodextrin concentration of $20 \%(\mathrm{w} / \mathrm{w})$. The outlet temperatures were ranged from $90-120^{\circ} \mathrm{C}$ 
and were increased with the increase of inlet temperature. At $160-170^{\circ} \mathrm{C}$ of inlet temperature, the outlet temperature falls within the range of $100-110^{\circ} \mathrm{C}$ to achieve powders with the lowest moisture and high quality (Caparino et al., 2012). The outlet temperature is mainly affected by the inlet temperature of the spray-dryer (Hui et al., 2008) and it is an important parameter as the outlet temperature affects the particle morphology and interparticle interactions between the sample and carrier (Maas et al., 2011).

The process yield of the kuini powder was the highest at $160-170^{\circ} \mathrm{C}$ and the lowest at 140 $150^{\circ} \mathrm{C}$. Nevertheless, the average yield (29.85$34.21 \%$ ) of powders produced in the second part of the experiment (different inlet temperatures) was slightly higher than the average yield $(21.66 \%-28.57 \%)$ of powders produced in the first part of the experiment (different maltodextrin concentrations) by up to $17 \%$, indicating the inlet temperature affecting the yield of powder. The feed flow rate for the spray-drying of kuini fruit showed no significant difference among all inlet temperatures tested $(p>0.05)$, probably because the feeds had consistent smoothness. Other than that, the powder produced at 140 and $180^{\circ} \mathrm{C}$ were coarse and sticky while the powder produced at $150-170^{\circ} \mathrm{C}$ was fine and soft. At a high temperature of $180^{\circ} \mathrm{C}$, the powder yield was lower, probably due to the high temperature that causes the sugar in the sample to undergo caramelisation and sticky to the drying chamber, led to lower yield and sticky appearance (Fitzpatrick et al., 2007). All powders produced appeared to be pale yellow.

\section{Effects of inlet temperature concentration on colour of spray-dried kuini powder}

The colour measurements which involved L*, $a^{*}$ and $b^{*}$ of the spray-dried kuini powder produced under different inlet temperatures can be observed from Table 5. There were no significant differences $(p>0.05)$ in the colour (in terms of $L^{*}, a^{*}$ and $b^{*}$ values) of the powders spray-dried at all the different temperatures were observed. All L* values were close to 100 , indicating all the spray-dried powders were light in colour as the positive $\mathrm{L}^{*}$ value indicated lightness while the negative $L^{*}$ value indicated darkness. The $a^{*}$ values and $\mathrm{b}^{*}$ values obtained were all positive values, signifying the powders produced were more reddish than greenish and more yellowish than bluish, respectively.

Table 4. The outlet temperature, process yield, feed flow rate, and powder conditions of kuini powder spray-dried at different drying inlet temperature and constant maltodextrin level $(20 \% \mathrm{w} / \mathrm{w})(\mathrm{n}=3)$.

\begin{tabular}{ccccl}
\hline $\begin{array}{c}\text { Inlet } \\
\text { temperature } \\
\left({ }^{\circ} \mathbf{C}\right)\end{array}$ & $\begin{array}{c}\text { Outlet } \\
\text { Temperature } \\
\left({ }^{\circ} \mathbf{C}\right)\end{array}$ & $\begin{array}{c}\text { Process Yield } \\
\mathbf{( \% )}\end{array}$ & $\begin{array}{c}\text { Feed Flow } \\
\text { Rate } \\
\mathbf{( g / m i n})\end{array}$ & \multicolumn{1}{c}{ Powder Conditions } \\
\hline 140 & $90-91$ & $29.85 \pm 1.18^{\mathrm{c}}$ & $5.57 \pm 0.37^{\mathrm{a}}$ & $\begin{array}{l}\text { Sticky and coarse powder } \\
\text { with pale yellow colour }\end{array}$ \\
150 & $94-99$ & $33.61 \pm 1.06^{\mathrm{bc}}$ & $5.46 \pm 0.12^{\mathrm{a}}$ & $\begin{array}{l}\text { Fine and soft powder with } \\
\text { pale yellow colour } \\
\text { Fine and soft powder with } \\
\text { pale yellow colour }\end{array}$ \\
160 & $99-104$ & $43.08 \pm 2.77^{\mathrm{a}}$ & $5.23 \pm 0.19^{\mathrm{a}}$ & $\begin{array}{l}\text { Fine and soft powder with } \\
\text { pale yellow colour }\end{array}$ \\
170 & $105-110$ & $40.74 \pm 0.83^{\mathrm{a}}$ & $5.68 \pm 0.28^{\mathrm{a}}$ & $\begin{array}{l}\text { Sticky and coarse powder } \\
\text { with pale yellow colour }\end{array}$ \\
\hline
\end{tabular}

Data are presented as mean \pm standard deviation of triplicate determination. Within the same column, different superscripts are significantly different at $\mathrm{p} \leq 0.05$, as measured by the Tukey's HSD Test. Abbreviations: $\%=$ percent, ${ }^{\circ} \mathrm{C}=$ degree Celsius, $\mathrm{g} / \mathrm{min}=$ grams per minute.

\section{Effects of inlet temperature concentration on water activity and moisture content of spray- dried kuini powder}

Table 5 shows the water activity of the powders produced at different inlet temperatures (140- $\left.180^{\circ} \mathrm{C}\right)$. The water activity of the powders decreased significantly from $0.23 \pm 0.01 \mathrm{Aw}$ $\left(140^{\circ} \mathrm{C}\right)$ to $0.16 \pm 0.01 \mathrm{Aw}\left(170^{\circ} \mathrm{C}\right)$. It was then increased to $0.18 \pm 0.01 \mathrm{Aw}$ at $180^{\circ} \mathrm{C}$. Masniza et al. (2013) reported that the water activity of grape 
powder decreased when inlet temperature increased. At higher inlet temperatures, the temperature gradient between the atomised feed and the drying air is greater, leading to the production of powder that has a lower moisture content (Tonon et al., 2008). Hence, the low moisture content was correlated to low water activity, indicating less free water is available. All the kuini powders produced under different inlet temperatures were considered microbiologically stable as the water activity level was lower than 0.6 (Cauvain \& Young, 2008). In terms of water activity level, powders produced at $160-170^{\circ} \mathrm{C}$ were the most favourable. Meanwhile, the moisture contents of the powders produced at inlet temperatures of $140-180^{\circ} \mathrm{C}$ are presented in Table 5. It ranged from $2.38 \pm 0.79 \%$ to $4.31 \pm$ $1.20 \%$ with no significant difference ( $p>0.05)$.

\section{Effects of inlet temperature concentration on bulk density of spray-dried kuini powder}

Table 5 displays the bulk density of the spraydried kuini powder under different inlet temperatures $\left(140-180^{\circ} \mathrm{C}\right)$. From the results obtained, the bulk density of the powders was within the range $(0.3-0.7 \mathrm{~g} / \mathrm{mL})$ of the usual bulk density level of spray-dried powder (Hui et al. 2008). Bulk density of powders formed was the highest at an inlet temperature of $160{ }^{\circ} \mathrm{C}$ and the lowest at $180^{\circ} \mathrm{C}(\mathrm{p} \leq 0.05)$. The bulk density of powder increased as inlet temperature increased from $140^{\circ} \mathrm{C}$ to $160^{\circ} \mathrm{C}$, but then dropped when the inlet temperature was further increased to $170^{\circ} \mathrm{C}$ and $180^{\circ} \mathrm{C}$.

As reported by Tonon et al. (2008), powders spray-dried under lower inlet temperature tend to have higher moisture content. Higher moisture content that is present in the powder causes the powder to stick together, leaving more interspaces between the particles, leading to larger bulk volume and lower bulk density (Phisut, 2012). Then again, excessive inlet temperature can cause lower bulk densities as rapid evaporation of the liquids can cause the dried particle droplets to expand rapidly, forming porous and hollow particles (Neikov et al., 2009; Sarabandi et al., 2014). These explained the pattern of the bulk density of the powders formed. Higher bulk density products are preferred because they occupy less space, have lower oxidation possibilities and better storage stability (Oliveira et al., 2010). Hence, the powder produced at $160^{\circ} \mathrm{C}$ is the most favourable in terms of bulk density.

Effects of inlet temperature concentration on water solubility index and wettability of spray-dried kuini powder

The WSI of spray-dried kuini powder at different inlet temperatures $\left(140-180^{\circ} \mathrm{C}\right)$ is shown in Table 5. The WSI of the powder produced from the different inlet temperatures ranges from $77.56 \pm$ $1.10 \%$ to $80.55 \pm 1.64 \%$ with no significant difference at $\mathrm{p}>0.05$. Phisut (2012) noted that maltodextrin has superior water solubility. This is possibly the reason for this observation. The WSI of the kuini powders produced in this section was lower when compared to $81.56 \%$ in pineapple juice powder (Abadio et al., 2004) that was added with $15 \%(\mathrm{w} / \mathrm{w})$ maltodextrin.

The wettability of powders obtained from different spray drying temperatures $\left(140-180^{\circ} \mathrm{C}\right)$ can be observed in Table 5. Based on Table 5, the wettability time of powder is significantly lowest at $140^{\circ} \mathrm{C}$. Powders produced at $170^{\circ} \mathrm{C}$ and $180^{\circ} \mathrm{C}$ have the highest wettability time. The wettability time increased with increase inlet temperature, which indicates that a longer time is needed for the particles to be penetrated by water (Marques et al., 2014). Hence, powders with lower wettability value were more favourable. The result obtained was similar to the production of green corn extract powder by Marques et al. (2014) where the powder produced at $140^{\circ} \mathrm{C}$ was the most favourable in terms of wettability time. A wettability value of $<300 \mathrm{~s}$ was a good parameter in fruit juices (Lannes \& Medeiros, 2003). Therefore, the powders produced at an inlet temperature of $150-170^{\circ} \mathrm{C}$ can be classified to have good wettability property.

\section{Effects of inlet temperature concentration on hygroscopicity of spray-dried kuini powder}

Table 5 presents the hygroscopicity of kuini powders obtained from different inlet temperatures $\left(140-180^{\circ} \mathrm{C}\right)$. The hygroscopicity of powders produced at the different drying temperatures showed no significant difference $(\mathrm{p}$ $>0.05$ ) and ranged from $21.64 \pm 0.69 \mathrm{~g} / 100 \mathrm{~g}$ to $22.41 \pm 0.73 \mathrm{~g} / 100 \mathrm{~g}$. This indicates the inlet temperature did not affect the hygroscopicity of the powder. 
Table 5. Physicochemical analyses of spray-dried kuini powder under different inlet temperatures and constant maltodextrin level $(20 \% \mathrm{w} / \mathrm{w})(\mathrm{n}=3)$.

\begin{tabular}{lccccc}
\hline \multirow{2}{*}{ Analyses } & \multicolumn{5}{c}{ Inlet Temperature $\left({ }^{\circ} \mathbf{C}\right)$} \\
\cline { 2 - 5 } & $\mathbf{1 4 0}$ & $\mathbf{1 5 0}$ & $\mathbf{1 6 0}$ & $\mathbf{1 7 0}$ & $\mathbf{1 8 0}$ \\
\hline Colour $\left(\mathrm{L}^{*}\right)$ & $90.26 \pm 0.47^{\mathrm{a}}$ & $90.06 \pm 0.27^{\mathrm{a}}$ & $90.37 \pm 0.36^{\mathrm{a}}$ & $89.87 \pm 0.52^{\mathrm{a}}$ & $90.72 \pm 0.96^{\mathrm{a}}$ \\
Colour $\left(\mathrm{a}^{*}\right)$ & $2.00 \pm 0.35^{\mathrm{a}}$ & $2.18 \pm 0.46^{\mathrm{a}}$ & $1.80 \pm 0.17^{\mathrm{a}}$ & $1.98 \pm 0.72^{\mathrm{a}}$ & $1.62 \pm 0.39^{\mathrm{a}}$ \\
Colour $\left(\mathrm{b}^{*}\right)$ & $29.01 \pm 2.58^{\mathrm{a}}$ & $30.54 \pm 1.30^{\mathrm{a}}$ & $29.69 \pm 0.78^{\mathrm{a}}$ & $30.26 \pm 0.72^{\mathrm{a}}$ & $28.25 \pm 2.91^{\mathrm{a}}$ \\
$\begin{array}{l}\text { Water Activity } \\
\left(\mathrm{A}_{\mathrm{w}}\right)\end{array}$ & $0.23 \pm 0.01^{\mathrm{a}}$ & $0.20 \pm 0.01^{\mathrm{b}}$ & $0.17 \pm 0.01^{\mathrm{cd}}$ & $0.16 \pm 0.01^{\mathrm{d}}$ & $0.18 \pm 0.01^{\mathrm{bc}}$ \\
$\begin{array}{l}\text { Moisture Content } \\
(\%)\end{array}$ & $4.31 \pm 1.20^{\mathrm{a}}$ & $3.55 \pm 0.84^{\mathrm{a}}$ & $3.03 \pm 0.53^{\mathrm{a}}$ & $2.77 \pm 0.38^{\mathrm{a}}$ & $2.38 \pm 0.79^{\mathrm{a}}$ \\
$\begin{array}{l}\text { Bulk Density } \\
\text { (g/mL) }\end{array}$ & $0.50 \pm 0.01^{\mathrm{c}}$ & $0.52 \pm 0.01^{\mathrm{bc}}$ & $0.55 \pm 0.01^{\mathrm{a}}$ & $0.53 \pm 0.01^{\mathrm{b}}$ & $0.47 \pm 0.01^{\mathrm{d}}$ \\
$\begin{array}{l}\text { WSI }(\%) \\
\text { Wettability (s) }\end{array}$ & $195.00 \pm 1.30^{\mathrm{a}}$ & $77.56 \pm 1.10^{\mathrm{a}}$ & $79.70 \pm 1.85^{\mathrm{a}}$ & $80.55 \pm 1.64^{\mathrm{a}}$ & $80.54 \pm 0.70^{\mathrm{a}}$ \\
$\begin{array}{l}\text { Hygroscopicity } \\
\text { (g/100g) }\end{array}$ & $253.67 \pm 21.63^{\mathrm{b}}$ & $279.00 \pm 7.90^{\mathrm{ab}}$ & $298.33 \pm 18.23^{\mathrm{a}}$ & $313.00 \pm 7.94^{\mathrm{a}}$ \\
\hline
\end{tabular}

Data are presented as mean \pm standard deviation of triplicate determination. Within the same row, different superscripts are significantly different at $\mathrm{p} \leq 0.05$, as measured by the Tukey's HSD Test. Abbreviations: $\%=$ percent, ${ }^{\circ} \mathrm{C}=$ degree Celsius, $\mathrm{L}^{*}=$ degree of lightness and darkness, $\mathrm{a}^{*}=$ degree of redness or greenness, $\mathrm{b}^{*}=$ degree of yellowness or blueness, $\mathrm{A}_{\mathrm{w}}=$ water activity, $\mathrm{g} / \mathrm{mL}=$ gram per millilitre, WSI $=$ Water Solubility Index, $\mathrm{s}=$ second, $\mathrm{g} / 100 \mathrm{~g}=$ gram per 100 grams.

Table 6. Physicochemical analyses of fresh kuini juice and optimised reconstituted powder.

\begin{tabular}{lcc}
\hline \multicolumn{1}{c}{ Analyses } & Kuini juice & Optimised reconstituted powder \\
\hline TSS $\left({ }^{\circ}\right.$ Brix $)$ & $12.37 \pm 0.46^{\mathrm{a}}$ & $12.56 \pm 0.45^{\mathrm{a}}$ \\
Viscosity $(\mathrm{cP})$ & $3661.20 \pm 118.90^{\mathrm{a}}$ & $619.70 \pm 16.50^{\mathrm{b}}$ \\
$\mathrm{pH}$ & $4.52 \pm 0.06^{\mathrm{a}}$ & $4.51 \pm 0.02^{\mathrm{a}}$ \\
Colour $\left(\mathrm{L}^{*}\right)$ & $54.94 \pm 0.87^{\mathrm{a}}$ & $48.44 \pm 1.68^{\mathrm{b}}$ \\
Colour $\left(\mathrm{a}^{*}\right)$ & $15.43 \pm 1.51^{\mathrm{a}}$ & $8.17 \pm 0.62^{\mathrm{b}}$ \\
Colour $\left(\mathrm{b}^{*}\right)$ & $68.61 \pm 1.99^{\mathrm{a}}$ & $56.17 \pm 2.66^{\mathrm{b}}$ \\
$\beta$-carotene content $(\mu \mathrm{g} / \mathrm{g})$ & $14.12 \pm 1.37^{\mathrm{a}}$ & $5.54 \pm 0.82^{\mathrm{b}}$ \\
\hline
\end{tabular}

Data are presented as mean \pm standard deviation of triplicate determination. Within the same row, different superscripts are significantly different at $\mathrm{p} \leq 0.05$ as measured by the paired sample T-test. Abbreviations: $\mathrm{TSS}=$ total soluble solid, ${ }^{\circ} \mathrm{Brix}=$ degree Brix, $\mathrm{cP}=$ centipoise, $\mathrm{L}^{*}=$ degree of lightness or darkness, $\mathrm{a}^{*}=$ degree of redness or greenness and $\mathrm{b}^{*}=$ degree of yellowness or blueness, $\mu \mathrm{g} / \mathrm{g}=$ microgram per gram.

\section{Optimum inlet temperature at optimum maltodextrin concentration}

At an optimum maltodextrin concentration of $20 \%(\mathrm{w} / \mathrm{w})$, the optimum inlet temperature was found to be $160^{\circ} \mathrm{C}$. The process yield of powder produced at this temperature was the highest at $43.08 \pm 2.77 \%$. The powder had a soft and fine texture as well as non-sticky characteristics with pale yellow colour, whereby it had $\mathrm{L}^{*}$ value of $90.37 \pm 0.36, a^{*}$ value of $1.80 \pm 0.17$ and $b^{*}$ value of $29.69 \pm 0.78$. The powder also had a low water activity level at $0.17 \pm 0.01 \mathrm{Aw}$ and the highest bulk density value of $0.55 \pm 0.01 \mathrm{~g} / \mathrm{mL}$. The powder formed under the same inlet temperature had a moisture content of $3.03 \pm 0.53 \%$, WSI of $79.70 \pm 1.85 \%$, good wettability value of 279.00 $\pm 7.90 \mathrm{~s}$, and hygroscopicity value $22.12 \pm 0.09$ $\mathrm{g} / 100 \mathrm{~g}$. This result was in accordance with the findings of Ersus and Yurdagel (2006), in which $160^{\circ} \mathrm{C}$ was selected as the optimal inlet temperature for the production of black carrot powder at $20 \% \quad(\mathrm{w} / \mathrm{w})$ maltodextrin concentration.

\section{Reconstitution of optimised kuini powder}

Table 6 describes the TSS, viscosity, $\mathrm{pH}$, colour and $\beta$-carotene content of fresh kuini juice and optimised reconstituted powder. The properties of optimised reconstituted powder and kuini juice were compared (Table 6). The TSS and $\mathrm{pH}$ were not significantly affected by spray-drying. However, the viscosity, colour and $\beta$-carotene 
content were affected by the spray-drying process. The viscosity of reconstituted kuini powder decreased from $3661.20 \pm 118.90 \mathrm{cP}$ to $619.70 \pm$ $16.50 \mathrm{cP}$ after spray-drying, indicating the solution produced had better consistency, which is favourable for industrial application. The heat treatment during the spray-drying process may attribute to this factor as the increase in inlet temperature would decrease the viscosity of the reconstituted powder. This is because the elevated temperature weakens the molecular interactions i.e. intermolecular hydrogen bonding that exhibited surface tension (Grabowski et al., 2006).

Apart from that, the reconstituted powder was less light and less redness and yellowness than the fresh kuini juice. This was possibly due to the addition of maltodextrin that causes the production of powder with pale colour and loss in red-orange colour. The destruction of $\beta$-carotene may also add to the loss of colour (Quek et al., 2007). The results were similar to the findings of Jittanit et al. (2010), whereby the powder showed less lightness compared to the juice. The overall difference in colour of fresh kuini juice and spraydried kuini powder was calculated to be $15.85 \pm$ 2.85. The total colour difference was higher compared to gac powder which had colour difference of around 10 when spray-dried at $160^{\circ} \mathrm{C}$ with $20 \% \quad(\mathrm{w} / \mathrm{w})$ maltodextrin concentration (Kha et al., 2010).

The $\beta$-carotene content of kuini was observed to be lower after spray-drying. The $\beta$-carotene content of the juice was $14.12 \pm 1.37 \mu \mathrm{g} / \mathrm{g}$ while the $\beta$-carotene content of the powder was $5.54 \pm$ $0.82 \mu \mathrm{g} / \mathrm{g}$. The recommended dietary intake of $\beta$ carotene is $3-6 \mathrm{mg} \beta$-carotene/day. Hence, with this guideline, the spray-dried kuini powder can be added as a supplementary source with other functional ingredients as one of the sources of $\beta$ carotene. The high temperature during the spraydrying process may contribute to this loss (Quek et al., 2007). This is because carotenoids are highly sensitive to high temperatures. The properties of optimised reconstituted powder were significantly different from the fresh kuini juice.

\section{CONCLUSION}

This work aimed to study the effects of maltodextrin concentration and inlet temperature on the properties of spray-dried kuini powder. The addition of $20 \%(\mathrm{w} / \mathrm{w})$ maltodextrin was optimal for the spray-drying of kuini, in which the kuini powder had considerable low moisture content $(2.16 \pm 0.60 \%)$, water activity level $(0.16$ $\pm 0.01 \mathrm{Aw})$ and hygroscopicity value (20.45 \pm $0.60 \mathrm{~g} / 100 \mathrm{~g})$. It also had a good wettability of $299.33 \pm 11.59$ s. With the increase of maltodextrin concentration from 5 to $20 \%$ (w/w), the lightness of the powders increased while their redness and yellowness decreased. In the second part of the experiment, it was found out that the optimum inlet temperature was at $160^{\circ} \mathrm{C}$. The powder obtained at this temperature has the highest yield of $43.08 \pm 2.77 \%$, the highest bulk density at $0.55 \pm 0.01 \mathrm{~g} / \mathrm{mL}$ and the lowest water activity level $(0.17 \pm 0.01 \mathrm{Aw})$. The wettability value was classified as good at $279.00 \pm 7.90$ s. In conclusion, the kuini powders formed at a spraydrying temperature of $160^{\circ} \mathrm{C}$ with the addition of $20 \%(\mathrm{w} / \mathrm{w})$ maltodextrin had the optimum properties. The reconstitution of optimised spraydried kuini powder had a lower viscosity, colour ( $\mathrm{L}^{*}, \mathrm{a}^{*}$ and $\mathrm{b}^{*}$ values), and $\beta$-carotene content as compared to fresh kuini juice. A future study can be conducted to use different drying aids (Arabic gum, cellulose, starch) to encapsulate the kuini powder in order to prevent loss of pigment during the spray drying process.

\section{REFERENCES}

Abadio, F. D. B., Domingues, A. M., Borges, S. V., \& Oliveira, V. M. 2004. Physical properties of powdered pineapple (Ananas comosus) juice - effect of malt dextrin concentration and atomization speed. Journal of Food Engineering 64: 285 287.

Adhikari, B., Howes, T., Bhandhari, B. R., \& Troung, V. 2004. Effect of addition of maltodextrin on drying kinetics and stickiness of sugar and acid-rich foods during convective drying: experiments and modelling. Journal of Food Engineering 62(1): 53-68.

Adnan, H., Mat Ali, M. S., Hassan, H., Abdul Manan, M., Ghazali, M. N., \& Ramli, N. S. N. 2018. Bioassay-guided of fresh and fermented kuini (Mangifera odorata) extracts against bacterial activity. International Journal of Agriculture, Forestry and Plantation, 7: 27-32.

Angel, R. C. M., Espinosa-Munoz, L. C., Aviles-Aviles, C., Gonzalez-Garcia, R., Moscosa-Santillan, M., GrajalesLagunes, A., \& Abud-Archil, M. 2009. Spray-drying of passion fruit juice using lactose-maltodextrin blends as the support material. Brazilian Archives of Biology and Technology 52(4): 1011-1018.

Barbosa Gámez, I., Caballero Montoya, K. P., Ledesma, N., Sáyago Ayerdi, S. G., García Magaña, M. de L., Bishop von 
Wettberg, E. J., \& Montalvo-González, E. 2017. Changes in the nutritional quality of five Mangifera species harvested at two maturity stages. Journal of the Science of Food and Agriculture 97(14): 4987-4994.

Cai, Y. Z. \& Corke, H. 2000. Production and properties of spraydried Amaranthus betacyanin pigments. Journal of Food Science 65(6): 1248-1252.

Cano-Chauca, M., Stringheta, P. C., Ramon, A. M., \& Cal-Vidal, J. 2005. Effects of the carriers on the microstructure of mango powder obtained by spray drying and its functional characterization. Innovative Food Science and Emerging Technologies 6: 420-428.

Caparino, O. A., Tang, J., Nindo, C. I., Sablani, S. S., Powers, J. R., \& Fellman, J. K. 2012. Effect of drying methods on the physical properties and microstructures of mango (Philippine 'Carabao' var.) powder. Journal of Food Engineering 111: 135148.

Carvalho, L. M. J., Gomes, P. B., Godoy, R. L. O., Pacheco, S., Monte, P. H. F., Carvalho, J. L. V., Nutti, M. R., Neves, A. C. K., Vieira, A. C. R. A., \& Ramos, S. R. R. 2012. Total carotenoid content, $\alpha$-carotene and $\beta$-carotene, of landrace pumpkins (Cucurbita moschata Duch): A preliminary study. Food Research International 47: 337-340.

Cauvain, S., \& Young, L. 2008. Bakery Food Manufacture and Quality (pp. 178-188). Oxford: Blackwell Science.

Chang, L. S., Eau Yong, S. M., \& Pui, L. P. 2020a. Production of spray-dried "Terung asam" (Solanum lasiocarpum Dunal) powder. Walailak Journal of Science and Technology 18(1).

Chang, L. S., Karim, R., Sabo Mohammed, A., \& Mohd Ghazali, H. 2018a. Production and characterization of enzymetreated spray-dried soursop (Annona muricata L.) powder. Journal of Food Process Engineering 41(e:12688). Blackwell Publishing Inc.

Chang, L. S., Tan, Y. L., \& Pui, L. P. 2020b. Production of spraydried enzyme-liquefied papaya (Carica papaya L.) powder. Brazilian Journal of Food Technology 23: e2019181.

Chang, L. S., Karim, R., Abdulkarim, S. M., Yusof, Y. A., \& Ghazali, H. M. 2018b. Storage stability, color kinetics and morphology of spray-dried soursop (Annona muricata L.) powder: effect of anticaking agents. International Journal of Food Properties 21(1): 1937-1954. Taylor \& Francis.

Chew, S., Tan, C., Pui, L., Chong, P., Gunasekaran, B., \& Nyam, K. 2019. Encapsulation technologies: A tool for functional foods development. International Journal of Innovative Technology and Exploring Engineering 8(5S): 154-160.

El-Samahy, S. K., El-hady, E. A. A., Habiba, R. A., \& MoussaAyoub, T. E. 2007. Some functional, chemical, and sensory characteristics of cactus pear rice-based extrudates. Journal of the Professional Association for Cactus Development Dec: 136147.

Ersus, S. \& Yurdagel, U. 2006. Microencapsulation of anthocyanin pigments of black carrot (Daucuscarota L.) by spray drier. Journal of Food Engineering 80: 805-812.

Fang, Z. \& Bhandari, B. 2012. Comparing the efficiency of protein and maltodextrin on spray drying of bayberry juice. Food Research International 48: 478-483.

Ferrari, C. C., Germer, S. P. M., \& de Aguirre, J. M. 2012. Effects of spray-drying conditions on the physicochemical properties of blackberry powder. Drying Technology 30(2): 154-163.

Fitzpatrick, J. J., Hodnett, M., Twomey, M., Cerqueira, P. S. M., O'Flynn, J., \& Roos, Y. H. 2007. Glass transition and the flowability and caking of powders containing amorphous lactose. Powder Technology 178(2): 119-128.

Gallali, Y. M., Abujnah, Y. S., \& Bannani, F. K. 2000. Preservation of fruits and vegetables using solar drier: a comparative study of natural and solar drying, III; chemical analysis and sensory evaluation data of the dried samples (grapes, figs, tomatoes and onions). Renewable Energy 19: 203-212.

Gallo, L., Llabot, J. M., Allemandi, D., Bucalá, V., \& Piña, J. 2011. Influence of spray-drying operating conditions on Rhamnus purshiana (Cáscara sagrada) extract powder physical properties. Powder Technology 208(1): 205-214. Elsevier B. V.

Gopinathan, M., Yusof, Y. A., \& Pui, L. P 2020. Effects of different drying methods on the physicochemical and antioxidant content of 'cempedak' (Artocarpus integer L.) powder. Journal of Food Processing and Preservation: in press.

Goula, A. M. \& Adamopoulos, K. G. 2010. A new technique for spray drying orange juice concentrate. Innovative Food Science and Emerging Technologies 11: 342-351.

Grabowski, J. A., Truong, V. D., \& Daubert, C. R. 2008. Nutritional and rheological characterization of spray dried sweet potato powder. LWT - Food Science and Technology 41: 206-216.

Grabowski, J. A., Truong, V. D., \& Dubert, C. R. 2006. Spraydrying of amylase hydrolyzed sweet potato puree and physicochemical properties of powder. Journal of Food Science 71(5): 209-217.

Hui, Y. H., Clary, C., Farid, M. M., Fasina, O. O., Noomhorm, A., \& Welti-Chanes, J. 2008. Food Drying Science and Tecbnology: Microbiology, Chemistry, Applications. DEStech Publications, Inc.

Jaya, S. \& Das, H. 2004. Effect of maltodextrin, glycerol monostearate and tricalcium phosphate on vacuum dried mango powder properties. Journal of Food Engineering 6: 125134.

Jittanit, W., Niti-Att, S., \& Techanuntachaikul O. 2010. Study of spray drying of pineapple juice using maltodextrin as an adjunct. Chiang Mai Journal of Science 37(3): 498-506.

Kader, A. A., Zagory, D., Kerbel, E. L., \& Wang, C. Y., 2009. Modified atmostphere packaging of fruits and vegetables. Critical Reviews in Food Science and Nutrition 28(1): 1-30.

Kha, T. C., Nguyen, M. H., \& Roach, P. D. 2010. Effects of spray drying conditions on the physicochemical and antioxidant properties of the Gac (Momordica cochinchinensis) fruit aril powder. Journal of Food Engineering 98: 385-392.

Kozai, N., Keizer, M., dela Cruz, F., Sajise, P. E., \& Idris, S. 2005. The marketing channel of two underutilized fruit species of Malaysia: Pulasan (Nephelium ramboutan-ake (Labill.) Leech) and Kuini (Mangifera odorata Griff.).

Lai, J. T., Lai, K. W., Zhu, L. Y., Nyam, K. L., \& Pui, L. P. 2020. Microencapsulation of Lactobacillus plantarum $299 \mathrm{v}$ and its storage in kuini juice. Malaysian Journal of Microbiology 16(4): 235-244.

Lannes, S. C. S. \& Medeiros, M. L. 2003. Cupuassu chocolate drink powder processed by spray-dryer. Brazilian Journal of Pharmaceutical Sciences 39(1): 115-123.

Lasano, N. F., Hamid, A. H., Karim, R., Dek, M. S. P., Shukri, R., \& Ramli, N. S. 2019. Nutritional composition, anti-diabetic properties and identification of active compounds using UHPLC-ESI-orbitrap-MS/MS in Mangifera odorata L. peel and seed kernel. Molecules 24(2): 1-20.

Lim, T. K. 2012. Edible medicinal and non-medicinal plants (Vol. 1, pp. 127-129). Dordrecht, The Netherlands: Springer.

Loo, Y. Y. \& Pui, L. P. 2020. Storage stability of kuini (Mangifera odorata) powder in aluminum laminated polyethylene and polyethylene terephthalate. Malaysian Journal of Analytical Sciences: in press.

Maas, S. G., Schaldach, G., Littringer, E. M., Mescher, A., Griesser, U. J., Braun, D. E., Walzel, P. E., et al. 2011. The impact of spray drying outlet temperature on the particle morphology of mannitol. Powder Technology 213(1): 27-35.

Marques, G. R., Borges, S. V., Mendonca, K. S., Fernandes, R. V. B., \& Menezes, E. G. T. 2014. Application of maltodextrin 
in green corn extract powder production. Powder Technology 263: 89-95.

Masniza, M., Hani Izzati, M. H., Farah Salina, H., \& Rinani Shima, A. R. 2013. Maltodextrin encapsulation of Garcinia atroviridis Griff by spray drying technique. International Journal of Scientific Engineering and Technology 2(10): 1011-1012.

Mishra, P., Mishra, S., \& Mahanta, C. L. 2013. Effect of maltodextrin concentration and inlet temperature during spray drying on physicochemical and antioxidant properties of amla (Embilica officinalis) juice powder. Food and Bioproducts Processing 92(3): 1-7.

Ndawula, J., Kabasa, J. D., \& Byaruhanda, Y. B. 2004. Alterations in fruit and vegetable $\beta$-carotene and vitamin $C$ content caused by open-sun drying, visqueen-covered and polyethylene-covered solar-dryers. African Health Sciences $4(2): 125-130$

Neikov, O. D., Naboychenko, S. S., and Dowson, G., 2009. Handbook of Non-Ferrous Metal Powders: Technologies and Applications. Elsevier.

Oliveira, W. P., Souza, C. R. F., Kurozawa, L. E., \& Park, K. J. 2010. Spray drying of food and herbal products. In Woo, M.W., Mujumdar, A.S., and Daud, W.R.W (eds.). Spray Drying Technology, pp.113-154.

Oms-Oliu, G., Rojas-Grau, M. A., Gonzalez, L. A., Varela, P., Soliva-Fortuny, R., Hernando, M. I. H., Munuera, I. P., Fiszman, S., \& Marin-Belloso, O. 2010. Recent approaches using chemical treatments to preserve quality of fresh-cut fruit: A review. Postharvest Biology and Technology 57(3): 139148.

Phisut, N. 2012. Spray drying technique of fruit juice powder: some factors influencing the properties of product. International Food Research Journal 19(4): 1297-1306.

Phoungchandang, S., \& Sertwasana, A. 2010. Spray-drying of ginger juice and physicochemical properties of ginger powders. Science Asia 36(1): 40-45.

Pui, L. P., Karim, R., Yusof, Y. A., Wong, C. W., \& Ghazali, H. M. 2018. Physicochemical and sensory properties of selected 'cempedak' (Artocarpus integer L.) fruit varieties. International Food Research Journal 25(2): 861-869.

Pui, L. P., Karim, R., Yusof, Y. A., Wong, C. W., \& Ghazali, H. M. 2020a. Anti-caking agent effects on the properties of spraydried 'cempedak' fruit powder. Journal of Tropical Agricultural Science: in press.

Pui, L. P., Karim, R., Yusof, Y. A., Wong, C. W., \& Ghazali, H. M. 2020b. Optimization of spray-drying parameters for the production of 'Cempedak' (Artocarpus integer) fruit powder. Journal of Food Measurement and Characterization: 1-12.

Quek, S. Y., Chok, N. K., \& Swedlund, P. 2007. The physicochemical properties of spray-dried watermelon powders. Chemical Engineering and Processing 46: 386-392.

Ribeiro, S. M. R., Humberto de Queiroz, J., Ribeiro de Queiroz, M. E. L., Campos, F. M., \& Sant'ana, H. M. P. 2007. Antioxidant in mango (Mangifera indica L.) pulp. Plant Foods for Human Nutrition 62: 13-17.

Rodriguez-Hernandez, G. R., Gonzalez-Garcia, R., GrajalesLagunes, A., \& Ruiz-Cabrera, M. A. 2005. Spray-drying of cactus pear juice (Opuntia streptacantha): Effect on the physicochemical properties of powder and reconstituted product. Drying Technology 23(4): 955-973.

Sarabandi, Peighambardoust, S. H., \& Shirmohammadi, M. 2014. Physical properties of spray dried grape syrup as affected by drying temperature and drying aids. International Journal of Agriculture and Crop Sciences 7(12): 928-934.

Shavakhi, F., Boo, H. C., Osman, A., \& Ghazali, H. M. 2012. Effects of enzymatic liquefaction, maltodextrin concentration, and spray-dryer air inlet temperature on pumpkin powder characteristics. Food and Bioprocess Technology 5(7): 2837-2847.
Singh, V. K., Mandhyan, B. L., Pandey, S., \& Singh, R. B. 2013. Process development for spray drying of ber (Ziziphus junbe L.) juice. American Journal of Food Technology 8(3): 183-191.

Tonon, R. V., Brabet, C., \& Hubinger, M. D. 2008. Influence of process conditions on the physicochemical properties of acai (Euterpe oleraceae Mart.) powder produced by spray drying. Journal of Food Engineering 88: 411-418.

Truong, V., Bhandari, B. R., \& Howes, T. 2005. Optimization of co-current spray drying process of sugar-rich foods. Part I - Moisture and glass transition temperature profile during drying. Journal of Food Engineering 71(1): 55-65.

Wong, C. W., Pui, L. P., \& Ng, J. M. L. 2015. Production of spraydried Sarawak pineapple (Ananas comosus) powder from enzyme liquefied puree. International Food Research Journal 22(4): 1631-1636.

Vidović, S. S., Vladić, J. Z., Vaštag, Ž. G., Zeković, Z. P., \& Popović. L. M. 2014. Maltodextrin as a carrier of health benefit compounds in Satureja montana dry powder extract obtained by spray drying technique. Powder Technology 258: 209-215. 